\title{
Dynamical switching between different hippocampal rhythms
}

\author{
Anastasia I Lavrova ${ }^{1,3^{*}}$, Ekaterina A Zhuchkova ${ }^{2,3}$, Susanne Schreiber ${ }^{2,3}$, Lutz Schimansky-Geier ${ }^{1,3}$ \\ From Twentieth Annual Computational Neuroscience Meeting: CNS*2011 \\ Stockholm, Sweden. 23-28 July 2011
}

The hippocampal circuit can exhibit network oscillations in different frequency ranges ("gamma" - 30-80 Hz; "theta" - 4-12 Hz; as well as "theta/gamma" or a bursting regime) both in vivo and in vitro and switch between them [1]. These different oscillatory modes facilitate memory storage in the hippocampus and memory consolidation $[2,3]$. The hippocampal neuronal network consists of various types of connected cells that differ in morphology and functional properties, which allows them to provide oscillations with different periods, amplitudes, and phase shifts [1]. Dynamical switching between various rhythms is likely to depend on the local network structure of the neurons.

Our goal is to investigate how coupling strength and delayed propagation influence synchronization and switching between different oscillatory states in minimal neuronal networks. To this end, we constructed a simple model of neurons comprising two fast-spiking and two slow-spiking cells, respectively. Cells are synaptically connected in an all-to-all manner, with exception of the two slow-spiking cells. The network is described by coupled FitzHugh-Nagumo equations that well reproduce the dynamical behavior of different cells types: their periods, amplitudes, and phase shifts.

The model allows us to analyze the influence of synaptic strengths on the network synchronization and dynamical switching between theta, gamma, and bursting regimes. In particular, we perform a thorough bifurcation analysis and identify parameters of synaptic connections that can efficiently induce switches in the network activity. We show that depending on the coupling strengths between slow- and fast-spiking cells, abrupt changes between different rhythms can occur, similar to experimental observations.

\footnotetext{
* Correspondence: aurebours@googlemail.com

${ }^{1}$ Institute for Physics, Humboldt-Universität zu Berlin, Berlin, 12489, Germany Full list of author information is available at the end of the article
}

\section{Acknowledgments}

This work was supported by the BMBF (BCCN Berlin, BPCN).

\section{Author details}

${ }^{1}$ Institute for Physics, Humboldt-Universität zu Berlin, Berlin, 12489, Germany. ${ }^{2}$ Institute for Theoretical Biology, Humboldt-Universität zu Berlin, Berlin, 10115, Germany. ${ }^{3}$ Bernstein Center for Computational Neuroscience, Berlin, 10115, Germany.

Published: 18 July 2011

\section{References}

1. Gloveli T, Kopell N, Dugladze T: Neuronal activity patterns during hippocampal network oscillations in vitro. Hippocampal Microcircuits 2010, 5(1):247-276.

2. O'Keefe J, Recce ML: Phase relationship between hippocampal place units and the EEG theta rhythm. Hippocampus 1993, 3:317-330.

3. Harris KD, Csicsvari J, Hirase H, Dragoi G, Buzsaki G: Organization of cell assemblies in the hippocampus. Nature 2003, 424:552-556.

doi:10.1186/1471-2202-12-S1-P284

Cite this article as: Lavrova et al:: Dynamical switching between different hippocampal rhythms. BMC Neuroscience 2011 12(Suppl 1):P284.

\section{Submit your next manuscript to BioMed Central and take full advantage of:}

- Convenient online submission

- Thorough peer review

- No space constraints or color figure charges

- Immediate publication on acceptance

- Inclusion in PubMed, CAS, Scopus and Google Scholar

- Research which is freely available for redistribution

Submit your manuscript at www.biomedcentral.com/submit

\section{() Biomed Central}

\section{() Biomed Central}

